\title{
Sheep and goat nematode resistance to anthelmintics: pro and cons among breeding management factors
}

\author{
Anne Silvestrea*, Vincent Leignel ${ }^{b}$, Boumadiane BerRaG ${ }^{\mathrm{c}}$, \\ Nadine GASNIER ${ }^{\mathrm{a}}$, Jean-François HUMBerT ${ }^{\mathrm{d}}$, Christophe CHARTIER ${ }^{\mathrm{e}}$, \\ Jacques CABARET ${ }^{\mathrm{a}}$ \\ a INRA, Pathologie Aviaire et Parasitologie, 37380 Nouzilly, France \\ b Université du Maine, Biologie et Génétique Evolutive, avenue Olivier Messiaen, \\ 72000 Le Mans Cedex 09, France \\ ${ }^{\mathrm{c}}$ Institut Agronomique et Vétérinaire Hassan II, Rabat Instituts BP 6202, Rabat, Morocco \\ ${ }^{d}$ INRA, Hydrobiologie Lacustre, 75 av. de Corzent, BP 511, 74203 Thonon, France \\ e AFSSA, Laboratoire d'études et de recherches caprines, 60 rue de Pied de Fond, BP 3081, \\ 79012 Niort Cedex, France
}

(Received 22 November 2001; accepted 28 February 2002)

\begin{abstract}
Although the molecular bases of resistance to anthelmintic families have been intensively studied, the contributing factors for the development of anthelmintic resistance are less well known. Clear recommendations must be given to farmers in order to delay the onset of anthelmintic resistance. Until now, the main advice has concerned the reduction of treatment frequency in order to slow down the spread of resistance. Anthelmintic resistance development depends mostly on an efficient selection pressure. This means that a high treatment frequency is neither necessary nor sufficient to select for resistance. The contribution of resistant worms, which have survived an anthelmintic treatment, to the subsequent generation is the key factor that controls resistance spread. This point is illustrated by five surveys conducted on sheep and goat farms from France and Morocco. In the 52 farms studied, less than three anthelmintic treatments were given each year. Three characteristics of breeding management can be identified in the build up of anthelmintic resistance: (1) the introduction of resistant worms through the purchase of sheep/goats or the use of common pastures, grazed by several herds/flocks, (2) under-dosing of hosts and the repeated use of one class of drugs, (3) the size of the population in refugia (infective larvae on pastures) at the time of the treatment. The role played by these breeding management factors in selecting for resistance is discussed. The most efficient way to limit the increase of anthelmintic resistance remains the reduction of the selection pressure by drugs, and optimal timing to maximise their efficacy.
\end{abstract}

resistance / nematodes / anthelmintic / sheep / goat / breeding management

* Correspondence and reprints

Tel.: (33) 2 47427683; fax: (33) 2 47427774; e-mail: silvestr@tours.inra.fr 
Résumé - Résistance aux anthelminthiques des nématodes de chèvres et de moutons : le rôle du mode d'élevage. Bien que les bases moléculaires de la résistance aux différentes familles d'anthelminthiques aient été très étudiées, les facteurs permettant le développement de la résistance anthelminthique sont moins bien connus. Des recommandations claires sont nécessaires aux éleveurs si l'on souhaite retarder l'apparition de la résistance aux anthelminthiques. La principale recommandation a consisté à réduire la fréquence des traitements de façon à ralentir le développement de la résistance. Le développement de la résistance anthelminthique dépend essentiellement d'une pression de sélection efficace. Cela signifie qu'une forte fréquence de traitements n'est ni nécessaire ni suffisante pour sélectionner la résistance. La contribution des vers résistants, qui ont survécu au traitement anthelminthique, à la génération suivante est le facteur clé qui contrôle le développement de la résistance. Ce point est illustré par cinq enquêtes réalisées dans des élevages ovins et caprins de France et du Maroc. Dans les 52 élevages étudiés, moins de trois traitements anthelminthiques par an étaient réalisés. Trois conditions d'élevage ont pu être mises en évidence comme étant impliquées dans le développement de la résistance anthelminthique : (1) l'introduction de vers résistants par l'achat de moutons ou de chèvres, ou par l'usage de pâturages communs à plusieurs troupeaux, (2) le sous-dosage des hôtes et l'usage répété d'une seule classe d'anthelminthiques, (3) la taille de la population « en refuge » (larves infestantes sur le pâturage) au moment du traitement. Le rôle joué par ces trois conditions d'élevage dans la sélection de la résistance est discuté. Le moyen le plus efficace de limiter l'augmentation de la résistance aux anthelminthiques est de réduire la pression de sélection par les molécules et d'optimiser la date des traitements pour prolonger leur efficacité.

\section{résistance / nématode / anthelminthique / ovin / caprin / conditions d'élevage}

\section{Table of contents}

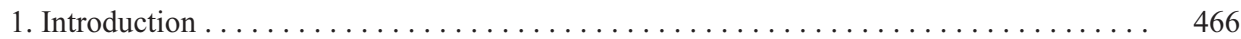

2. Introduction of animals harbouring anthelmintic resistant nematodes or grazing on common

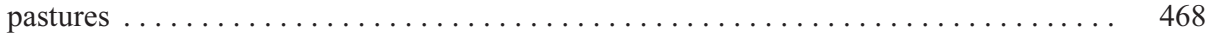

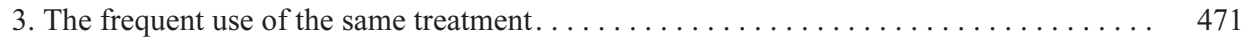

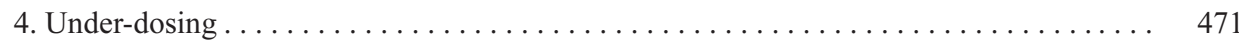

5. Size of the population in refugia at the time of the treatment $\ldots \ldots \ldots \ldots \ldots \ldots \ldots \quad 473$

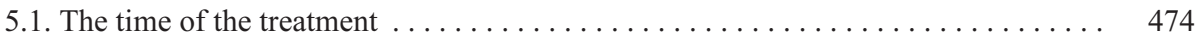

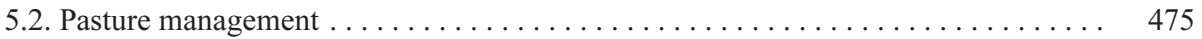

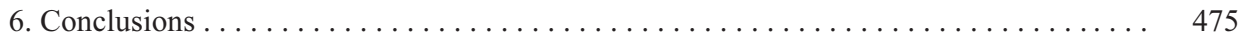

\section{INTRODUCTION}

Three broad spectrum anthelmintic families are currently used to control gastro-intestinal nematode infections of small ruminants: benzimidazoles, imidazothiazole/tetrahydropyrimidines and macrocyclic lactones. Benzimidazole resistance was first recorded in 1964, three years after thiabendazole was introduced commercially [34]. Similarly, a levamisole/morantel resistant strain was isolated in 1976 [65] and in 1987, resistance to macrocyclic lactones appeared in South Africa [20]. Anthelmintic resistance has been described as the situation when normal dosage of a drug does not promote a consistent reduction of worms or excreted eggs. Based on published data, Haemonchus contortus seems to be the species most involved in cases of anthelmintic resistance [10]. To control anthelmintic resistant 
strains, farmers usually switch to the use of another anthelmintic family, which may also select for future resistance. As a consequence, multiple resistance (i.e. resistance against more than one anthelmintic family) has appeared in field strains [44]. The same species can be prone to develop anthelmintic resistance in a particular host and not in another one, for instance in goats versus sheep [10] or in sheep versus cattle [26]. In a community of nematodes (several species of nematodes), one species can be resistant to an anthelmintic family and a second species to another drug. Several phenotypic tests are available to detect anthelmintic resistance: the faecal egg count reduction test, the egg hatch assay and the larval development test (for WAAVP recommendations [27, 101]). Although these tests have been widely used in surveys, they are not sensitive enough to detect resistance in a nematode community where each species is characterised by a particular pattern of drug resistance (towards a particular drug or not, and at various levels of resistance) and a highly variable prolificity. Thus "all communities of worms" resistance may fail to detect many cases. Haemonchus contortus is very prolific (5 000 eggs laid per female and per day) and Teladorsagia circumcincta less prolific (500 eggs/female/day) but five times more than Trichostrongylus colubri-formis [13]. For instance, a community is composed of $50 \%$ $H$. contortus and $20 \%$ T. circumcincta, both species susceptible to benzimidazoles, and $30 \%$ of $T$. colubriformis, fully resistant to benzimidazole. Excreted eggs are composed of $(5000 \times 0.5)+(500 \times 0.2)+(100 \times 0.3)$. After a benzimidazole treatment, only $T$. colubriformis would maintain egg excretion. A faecal egg count reduction test on this community would give a $98.8 \%$ reduction even though T. colubriformis was fully benzimidazole resistant.

Cases of anthelmintic resistance have been recorded more and more often, threatening small ruminant breeding $[30,77]$ and cases are also emerging in cattle [26, 29, 73, $90,97]$. Although many studies have enlightened the molecular basis for resistance to diverse anthelmintic families, reviewed by Sangster [81], few literature data are available concerning the factors responsible for anthelmintic resistance. It is commonly accepted that resistant genes exist as rare alleles in natural populations $[55,75$, 76], and that anthelmintic resistance develops when selection pressure is high. The main factor evoked to select for resistance concerns treatment frequency and, "a large number of anthelmintic treatments with the same anthelmintic family for years" is taken as the key factor for selecting for resistance [91]. This statement is supported by surveys realised on a regional scale, in New Zealand [59, 83]; in Malaysia [33]; in South Africa [95]; in the United Kingdom $[53,75]$; in Australia $[36,72]$. The "same" repeated anthelmintic treatment is a major cause, in experimental and oversimplified conditions (three-month-old lambs, synchronous infestation with only one to three gastro-intestinal nematode species...) of positive correlation between intensity of resistance and treatment frequency $[5,66$, 71]. A few authors have questioned the nature of the correlation observed between the number of treatments and resistance development [59, 87]. A high number of anthelmintic treatments illustrates two possible situations:

- a real case of anthelmintic resistance: farmers tend to treat their animals more often when they find that they respond less to treatments,

- or a case of high infection: the flock is ill-managed or the risk of infection is high and farmers maintain production using frequent anthelmintic treatments [17].

The selection of resistant worms by anthelmintic treatments cannot be denied in experimental conditions: a higher treatment frequency increases resistance selection [66], conversely, cases illustrate anthelmintic resistance development on goat and sheep 
farms where anthelmintic treatment frequency was less than two drenches a year, as if a high selection pressure by anthelmintic treatments was neither necessary nor sufficient to promote anthelmintic resistance development in real life $[28,42]$. This leads us to propose the following hypothesis: anthelmintic resistance may develop under an efficient [treatments are performed at "the right time"] rather than under apparent (number of treatments) selection pressure. A selection pressure is efficient when the resistant worms that survived the anthelmintic treatment can contribute for a large part to the subsequent worm generation. So, anthelmintic resistance development is a complex phenomenon, which implicates other factors than anthelmintic treatment frequency in itself [55]. We present the main breeding management factors that have been identified mostly throughout five surveys conducted on goat and sheep farms from France (Touraine, DeuxSèvres, Quercy and Auvergne) and Morocco (Middle Atlas and Rabat area) (Tab. I). Additional information on breeding management is available in $[25,87]$.

Breeding management encompasses a large variety of practices and includes supplementary food and grazing organisation, health hazard control, and an expected level of production and derived income, among others. In its wider meaning (a farm as a system of inter-related events and practices), the complexity of all factors results in that researchers present detailed casestudies (see for example [21]) and generalisation might become the problem of such investigations. Conversely, a particular trait of farms (derived income: [63], current pathology: [40]) and several characteristics of breeding management might be selected. More farms are then studied, but the choice of factors of interest might be controversial and their validity possibly limited to the pathology $[16,64]$, or production traits (milk or kid productions in goats: [15]). In our review, we will consider the latter orientation, since large detailed surveys on breeding management are not available in sheep and goats. The studies on the relationship between breeding management and nematode infection intensity are based on selected aspects of breeding management such as the number of treatments, the size of a herd or flock, its demography, the period at which lambing or kidding occurs, the intensity of pasture use, the type of pasture and its fertilisation $[11,12,18]$. These factors may play a role within the frame of a selection process for resistant worms. One may also consider that selection might have been previously achieved in another site and that resistant worms were introduced to the farms under study: in that case, the actual breeding management of these farms will provide a poor explanation of the occurrence of resistance. In fact, introduced resistant worms would probably be at a very low level in an ancient introduction, whereas a recent introduction may favour resistance since many farms harbour resistant worms.

\section{INTRODUCTION OF ANIMALS HARBOURING ANTHELMINTIC RESISTANT NEMATODES OR GRAZING ON COMMON PASTURES}

Anthelmintic resistance may be introduced from one farm to another through animal purchase or by grazing on pastures shared by flocks from several farms. In Spain, the first anthelmintic resistance recorded occurred after Cashmere goats were imported from the United Kingdom [78], where a high prevalence of anthelmintic resistance in fibre producing goats had been recorded [56]. The same situation was observed in Angora goats imported to Slovakia from New Zealand [96] and sheep imported to Greece from Great Britain [51]. In French dairy goat farms, no infected animals are introduced after the flock has been set up. 
Anthelmintic resistance and breeding management

469

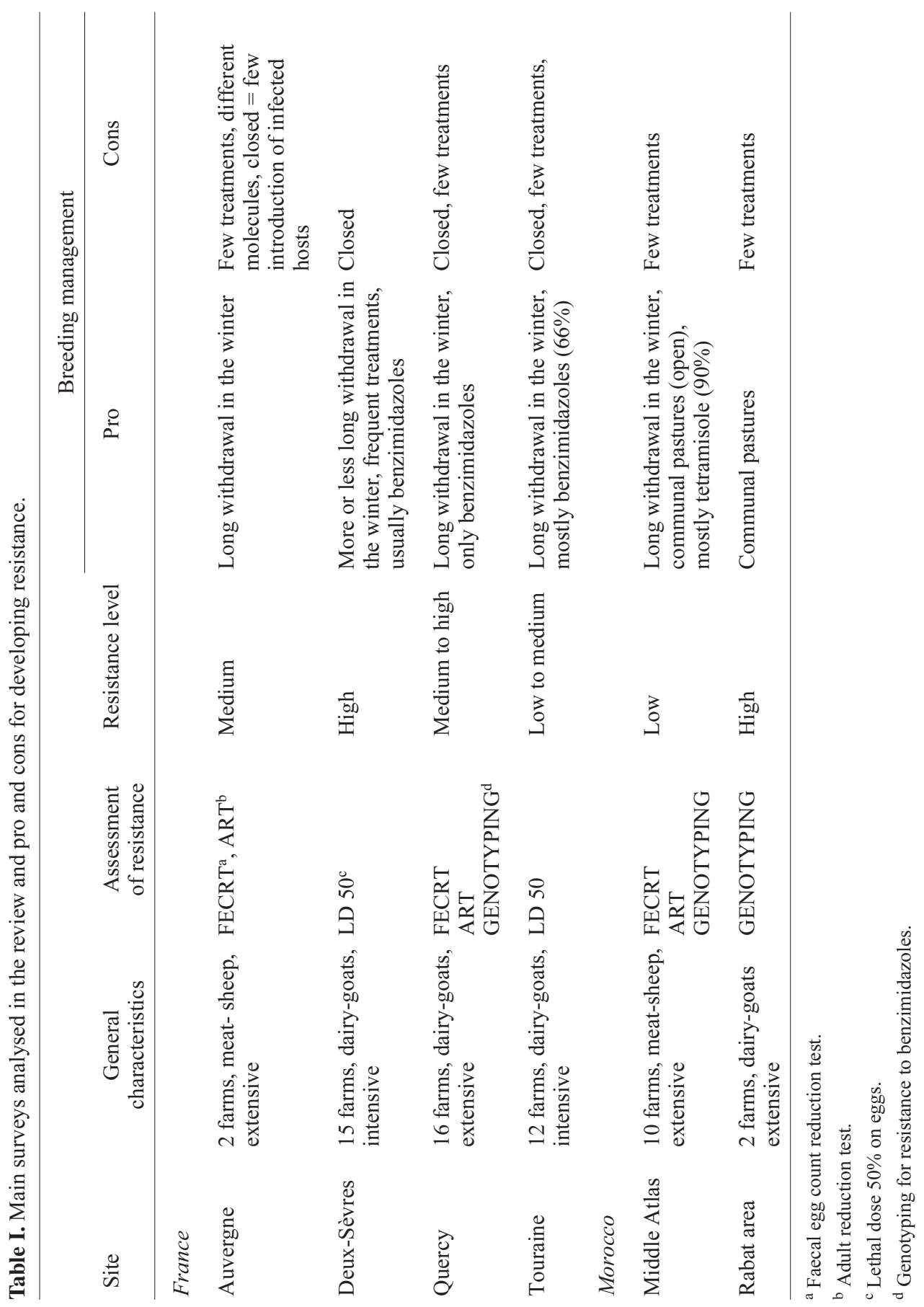


We can therefore expect that dairy goat farms are isolated as far as gastro-intestinal nematodes are concerned. It has been demonstrated that, in such isolated farms, the constitution of the flock is a critical step for the introduction of anthelmintic resistant parasites [86]. Farms that were constituted before benzimidazoles came to the market, should not have introduced resistant nematodes: the frequency of the resistant allele is very low in natural populations, so-called "susceptible populations". The age of the farm and the number of farms from which goats originated when the studied farm was created are correlated with the intensity of goat introduction in a survey on 16 farms in Quercy [87]. The intensity of the original introduction (expressed as the number of goats $\times$ number of farms from which the introduction was performed) is also a factor that significantly increased the risk of subsequent resistance in goat nematodes on 27 farms from Touraine and Deux-Sèvres ([41] and unpublished data). In order to clearly understand this point, we need to come back to the first step of resistance development. Anthelmintic resistance is thought to be a pre-adaptive character of nematodes and genes conferring resistance are available within the population as rare alleles, prior to the first exposure to the anthelmintic [80]. Resistance prevalence should then increase with time, in response to the growing of an efficient selection pressure. Thus, in the case of benzimidazoles for instance, farms that recently constituted their flocks, present a greater risk of introducing resistant worms than the ones that constituted their herds twenty years ago, at the beginning of the large commercialisation of benzimidazoles [87]. Moreover, the sizes of the herds are growing to ensure the economic viability of the farms, which favours the constitution of herds from an increasing number of farms as observed in Quercy [87].

Many farms have been closed to the introduction of strange nematodes for years since they have been increasing their flock/herd size from their own goats or ewes and/or buy new female reproducers at an early age from zero-grazing production selection farms. This general rule is broken in developed countries on two occasions: transhumance and the occurrence of pathologies that may kill part of the flock and thus subsequently imposes buying adult producers to re-start the farm. Transhumance is still practised for sheep (and goats in Switzerland [50]) in the south of France both in the Alps and in the Pyrenees: sheep are treated, then flocks are brought onto mountain pastures at the beginning of June and return to the plains at the end of September [46]. The flocks and herds are mixed for a long grazing period and may then acquire parasites from several farms. Thus in the Pyrenees, more than 300000 ewes and 30000 cattle are transhumant every year and obvious mixture of nematode origins is expected. The appearance of scrapie in a flock imposes the slaughter of a cohort(s) of sheep and is then a case of intense reintroduction as shown in the French Basque area [64]. This may possibly favour the introduction of resistant worms.

In developing countries, such as Morocco, Ait-Baba [1] reported that $60.5 \%$ of the alimentary needs of small ruminants are obtained from collective natural pastures, which is a source of unknown and possibly resistant nematodes. The proportion of sheep nematode genotypes resistant to benzimidazoles (Teladorsagia circumcincta) in the Middle Atlas, where transhumance and communal pastures are common, was $13 \%$ (from 50 adults worms recovered after a sheep experimental infestation with pooled infective larvae from 7 sheep farms, own unpublished results). In the plains of Morocco, no transhumance is performed but ruminants are grazed on communal pastures and the exchange of parasites between farms is then highly probable. Currently, at the abattoir of Rommani, in the plain, near Rabat, goats harboured as much as $46 \%$ 
benzimidazole resistant $T$. circumcincta (own unpublished results).

\section{THE FREQUENT USE OF THE SAME TREATMENT}

The frequent use of the same treatment is a way to efficiently select one sub-population of worms that presents the capability to survive one particular type of drug. On the contrary, the alternation of the anthelmintic family reduces the effect of the selection pressure exerted by each type of drug. In an experiment [66], we tested four regimens of treatments: lambs were allowed to graze paddocks that had been seeded with a benzimidazole resistant strain of $T$. circumcincta $(25 \%$ resistant worms). The effect of the exclusive use of benzimidazoles (three treatments the first year and, five treatments the second year) versus the alternative treatment with a nonbenzimidazole molecule (two benzimidazole treatments in alternation with one levamisole treatment the first year, and three benzimidazole treatments in alternation with two levamisole treatments the second year) on the resistant worm frequency was tested. At the end of a two-year investigation, the frequency of benzimidazole resistant worms reached $80 \%$ and $50 \%$ in the benzimidazole treated group, and the alternatively treated group, respectively. This significant difference demonstrates that the alternation of the anthelmintic family may slow down the selection of benzimidazole resistant worms during the early steps of resistance development.

The importance of benzimidazole resistance in goats for nematode parasites common to sheep is another illustration of the effect of the exclusive use of one anthelmintic family. For years, goats were treated regularly and almost exclusively, with benzimidazoles, because this family is compatible with milk production constraints. A survey conducted on 23 sheep farms and 15 dairy goat farms from western France [23] indicated that goats are drenched about 6.5 times a year (from 0 to 9 treatments) with benzimidazoles whereas ewes receive an average of 3.5 anthelmintic treatments per year (from 2 to 6 drenches). The benzimidazole family is the most frequently used ( $83 \%$ of all treatments), but it is not the only anthelmintic family since farmers can take advantage of the end of the lactating period to treat goats with imidazothiazoles or tetrahydropyrimidines $(45 \%$ of all treatments in Touraine) [17]. A recent analysis of the literature recorded by the Commonwealth Agricultural Bureau (CAB) [10], from 1973 to 1999 , indicated that goats harbour significantly more anthelmintic resistant nematode species than sheep, and the literature more frequently concerns benzimidazoles, which illustrates the effect of the frequent use of the same treatment on anthelmintic resistance selection.

\section{UNDER-DOSING}

Under-dosing occurs when a host is administered "a weight-dependant dose that is less than that recommended by the manufacturer" [89]. It results from a mis-estimation of bodyweight [100]. It is distinct from the bioavailability that concerns individual ruminants and results from the animal's physiology, feed intake before oral anthelmintic treatment, oesophageal groove reflex, ruminants degree of fatness... For years, under-dosing has been repeatedly blamed for the build up of resistance $[9,23$, $30,31,47,60,85]$. This hypothesis is supported by the fact that systematic under-dosing of goats, for the most widespread nematode species, has resulted in higher anthelmintic resistance in goats than in sheep [10]. Differences between the bioavailability and efficacy of a benzimidazole (albendazole) and a salicylanilide (closantel), in goats and sheep, lead goats to be under-dosed if the sheep dose is used [48, 49]. Dosages 1.5 (for levamisole) to 2 
(benzimidazoles, and possibly avermectins) times higher than those given to sheep (Tab. II) are now recommended for treating goats with most anthelmintics [22]. Under-dosing caused by the under-estimation of the animal's weight is nothing less than anecdotal since epidemiological surveys mention that bodyweights of sheep and goats are estimated by the eye $[8,36,67,68$, $83,100]$, and that anthelmintic doses are not calculated for the heaviest animals of the flock [32, 67, 68, 83, 100]. In French dairy goat herds, the bodyweight of goats was usually evaluated at more or less $50 \mathrm{~kg}$ in the 1980s [17] which grossly under-estimated the real weight of the goats. As a consequence, the anthelmintic dose calculated was systematically suboptimal [79].

Although under-dosing can be seen as a frequent phenomenon, only a few experi- ments were conducted to quantify the impact of under-dosing in selecting for anthelmintic resistance [37, 52, 69, 88]. A controlled trial was conducted on the experimental infections of sheep with a $T$. circumcincta strain, partially resistant to benzimidazoles. A recessive point mutation in the $\beta$-tubulin gene is responsible for benzimidazole resistance $[6,38,39,61$, $62]$. At the therapeutic dosage, only homozygous mutant nematodes survive benzimidazole treatment [38]. The efficacy of an anthelmintic against homozygous and heterozygous genotypes may vary according to the dose rate chosen. To some extent, the concept of dominance/recessivity is misleading in the under-dosing context. Experimentation has demonstrated that a dosage with $1 / 4$ of the recommended dose of Fenbendazole (a benzimidazole) gives a 4.5 times higher selective advantage to

Table II. Ovine and caprine recommended doses ( $\mathrm{mg} / \mathrm{kg}$ body weight) for the main molecules from benzimidazoles, imidazothiazoles/tetrahydropyrimidines, macrocyclic lactones and salicylanilides.

\begin{tabular}{llcc}
\hline Anthelmintics & Molecules & $\begin{array}{c}\text { Ovine dose } \\
\left(\mathrm{mg} / \mathrm{kg}^{\mathrm{a}}\right)\end{array}$ & $\begin{array}{c}\text { Caprine dose } \\
\left(\mathrm{mg} / \mathrm{kg}^{\mathrm{a}}\right)\end{array}$ \\
\hline Benzimidazoles and pro-benzimidazoles & Albendazole & 3.8 & 7.6 \\
& Febantel & 5 & 10 \\
& Thiabendazole & 50 & 100 \\
& Fenendazole & 15 & 30 \\
& Netobimin & 5 & 10 \\
& Oxfendazole & 5 & 15 \\
Imidazothiazoles/Tetrahydropyrimidines & Levamisole & 7.5 & 10 \\
& Pyrantel & 20 & 40 \\
Macrocyclic lactones & Eprinomectine & 0.5 & 0.5 up to 1 \\
& Ivermectine & 0.2 & 0.4 \\
\hline Salicylanilides & Closantel & 10 & 10 \\
\hline
\end{tabular}

${ }^{\mathrm{a}} \mathrm{mg} / \mathrm{kg}$ bodyweight. Adapted from $[22,24,35]$. 
heterozygous worms than to susceptible worms [88]. To study the long term effects of under-dosing, anthelmintic resistance development has been studied using diverse computer models [4, 88, 89], where resistance is determined by a major gene comprising two alleles (the resistant allele being recessive) at a single autosomal locus. The initial hypothesis was that under-dosing should favour resistance development to the extent that it would allow the survival of heterozygous worms (that would, usually, be eliminated by the therapeutic dose), for whom mating would then generate the first homozygous resistant worms. These three models clearly demonstrated that the dose rate that would promote the spread of anthelmintic resistance (i.e. an increase of resistant allele frequency from less than $0.1 \%$ to an almost resistant allele fixation, e.g. $100 \%$ resistant individuals) depends on the resistant allele frequency and the characteristics of the parasite population (worm fecundity, life span of adults, etc.) [89]. Actually, heterozygous worms represent a stock of resistant alleles in a susceptible population where resistant allele frequency is very low and inversely a stock of susceptible alleles in a resistant population. A dose that eliminates all susceptible worms and some heterozygous worms would select for anthelmintic resistance in a susceptible population. However in a resistant population, the same dose would slow down the fixation of the resistant allele: the survival of heterozygous worms would allow the conservation of susceptible alleles [89]. The same results were obtained in [88], using a stochastic model [82]. Both models indicated that the whole flock needs to be under-dosed for a long period of time and at a very precise dosage, corresponding to $1 / 4$ of the therapeutic dose for benzimidazoles, to promote selection of resistant alleles, which is probably not what occurs on farms. Thus, it seems that underdosing probably plays an occasional rather than a systematic role in benzimidazole re- sistance development in ruminants, except possibly for goats.

The same under-dosing history has been recorded for other anthelmintics such as tetramisole. The repeated use of tetramisole in the sheep of the Middle Atlas of Morocco [7] at the $10 \mathrm{mg} / \mathrm{kg}$ bodyweight (bw) instead of the $15 \mathrm{mg} / \mathrm{kg}$ bw dose comforts the limited role of under-dosing, whatever the anthelmintics. Tetramisole has been employed for more than 15 years at the $10 \mathrm{mg}$ dosage in sheep of the whole region; it is given at least once per year on the majority of the farms since it is obtained free for the farmers. On nine farms, the efficacy was low ( $74 \%$ reduction of faecal egg count) to nil at $10 \mathrm{mg} / \mathrm{kg}$ bw. When treatment was given at the standard $15 \mathrm{mg} / \mathrm{kg}$ bw, efficacy could reach $100 \%$ as tested on one farm. A pool of infective larvae (largely $T$. circumcincta) from the nine farms studied was given to lambs and efficacy at 10 and $15 \mathrm{mg} / \mathrm{kg}$ bw was tested. Faecal egg count reduction tests were respectively 40 and $80 \%$. Adult reduction was respectively 63 and $85 \%$ compared to the control. When the correct dose was given to the Moroccan sheep, the results were nearly identical to those obtained for $T$. circumcincta, by Walley [98] in Great-Britain: efficacy ranged from 24 to $78 \%$ (compared with $40 \%$ ), and from 81 to $92 \%$ (compared with $80 \%$ ) respectively, for 10 and $15 \mathrm{mg} / \mathrm{kg} \mathrm{bw}$. The generalised under-dosing for more than 15 years did not seem to erode the efficacy of tetramisole.

\section{SIZE OF THE POPULATION IN REFUGIA AT THE TIME OF THE TREATMENT}

The concept of refugia has been largely used (in biological control and agricultural entomology [43, 57, 92], phylogeography [99], conservation biology [45], and ecology [84] to cite a few). It corresponds to the fraction of the nematode population that is 
not submitted to selection pressure by a control measure [26,94]. The concept presents a spatial and temporal component when digestive-tract nematodes are considered: the part of the population in refugia corresponds to the free-living stages, located on pastures and not submitted to the anthelmintic treatment given to the hosts. Free-living stages represent more than $90 \%$ of the total population of gastro-intestinal nematodes of ruminants [2]. L4 larvae, encysted in the abomasum, are not considered in refugia since they are easily eliminated by a double dose of benzimidazoles [14]. The size of the population in refugia at the time of the anthelmintic treatment will determine the contribution of the surviving worms to the subsequent generation: this was presented by Van Wyk [93] as a major source of resistance. Through ecology or management practices, contamination after treatment may contribute substantially to future generations of worms. For years, farmers were recommended [74] to treat hosts and move them to pastures free of infective larvae (i.e. not grazed for at least one year or on sown pastures) in order to reduce the re-infection of the hosts. But, although this strategy is beneficial to controlling infection with susceptible worms, it becomes highly dangerous when anthelmintic resistant worms appear within the parasite population $[69,70]$. From this point of view, the time of the anthelmintic treatment and pasture management are important factors that can influence the rate of development of anthelmintic resistance.

\subsection{The time of the treatment}

In the surveys studied, it was a common feature to treat sheep and goats before turn out to pastures and in some cases, during housing (Quercy, Auvergne and Touraine) [87]. This strategy favours a high and efficient selection pressure on worms: in the winter, pastures harbour few infective larvae and animals host almost all the parasite population. In such a scheme, goats that are turned out on pastures at the beginning of the grazing season, only harbour adult worms that survived the anthelmintic treatments. Pastures are then contaminated by the eggs laid by resistant worms. The role played by these resistant eggs depends on the proportion of infective larvae that overwintered in the grass/soil. In France, climatic conditions should allow $T$. circumcincta free-living stages to survive better than other species in the winter [58]. Thus, the role of the population in refugia, in this situation, may be more important for species like $T$. circumcincta than for Haemonchus contortus or Trichostrongylus colubriformis, which are readily eliminated from pastures by low temperatures. Data allowing the comparison of the species composition of the nematode parasite community before and after anthelmintic resistance development are necessary to substantiate this statement. Published data on anthelmintic resistance reports seem to indicate that on the world scale, $H$. contortus is the species the most prone to develop anthelmintic resistance [10] and $T$. colubriformis presents the highest benzimidazole resistance level in southwestern France [25].

In the Touraine survey, one third of anthelmintic treatments were given at mating [17] between May and July during the grazing period. At this moment, the free-living stages on pastures represent a much more important part of the total population than the parasitic stages, harboured by the hosts. As a consequence, this treatment was not an efficient selection pressure: immediately after treatment, goats became re-infected with the infective larvae and the selective advantage given to adult worms that survived the treatment did not last enough to produce a large number of resistant eggs. This may explain that at the time of the survey (1984: see [16]) and even later (1992: see [41]) resistance to benzimidazoles remained moderate in 
prevalence in Touraine (approximately $50 \%$ of the farms) whereas it was much higher in Deux-Sèvres (93\%) where drenching periods were different (mostly at the end of the autumn-winter) [23].

\subsection{Pasture management}

Under a tropical climate, infective larvae do not survive more than a few days on the pasture [3]. As a consequence, the "treat and move" approach can efficiently select resistance when the first resistant worms appear. Nevertheless, in the present surveys from temperate areas, it seems more probable that the most efficient strategy to select for resistance by pasture management concerns the length of winter withdrawal of the hosts from the pastures. In the Quercy survey, farmers practise long winter withdrawal (from four to nine months) of goats from pastures [87]. At turn out, the infectivity of the pastures is probably extremely low, after winter climatic conditions have killed the free-living stages of most species [58]. As a consequence, the goats' worm burden consists almost completely of worms that survived anthelmintic treatment and may contribute to the spread of anthelmintic resistance. In Touraine and Deux-Sèvres, the winter withdrawal varies from nil to seven months in a 27 farm sample: the intensity of resistance is strongly correlated with the length of withdrawal ([41] and our own unpublished data).

A probably similar situation is available in the French Auvergne (unpublished data), at two studied INRA farms (Redon and Orcival, at $800 \mathrm{~m}$ and $1000 \mathrm{~m}$ above sea level, respectively). Sheep are maintained indoors from October (Orcival) or November (Redon) to the end of April (Redon) or May (Orcival). The ewes are treated three times and once a year in Redon and Orcival, respectively, whereas the lambs are treated twice a year in both sites [19]. The treatments given during the last five years were benzimidazoles $(35 \%)$, levamisole $(40 \%)$ and avermectins (25\%). The lambs were kept up to July and were sold as light young lambs, which did not permit the build-up of a high level of infection and explains the low number of treatments. The sheep were initially kept in Redon and one part of the flock was introduced to Orcival 15 years ago. Both farms are closed and do not introduce sheep from other farms. The efficacy of benzimidazole treatment (Fenbendazole $5 \mathrm{mg} / \mathrm{kg}$ bw) was $67 \%$ (Redon) and $100 \%$ (Orcival) based on the faecal egg count reduction test. The efficacy based on the adult reduction test was $72 \%$ (Redon) and $73 \%$ (Orcival). Resistance was then acquired in situations of low intensity of treatments, but with high efficacy in selecting resistant worms: the ewes were treated when they were indoors and only resistant worms survived, they then seeded pastures the next spring, which had become nearly void of infective larvae of most nematode species (except Nematodirus sp., or Teladorsagia circumcincta $[46,58])$ due to the long winter withdrawal.

\section{CONCLUSIONS}

In the five surveys described in this paper, anthelmintic resistance spread was not a consequence of a high selection pressure by high anthelmintic treatment frequency (except for Deux-Sèvres). These surveys illustrate the role of three factors that are summarised in Table I:

- the introduction of resistant worms through sheep/goat purchase, and the area of pastures shared by several farms, named "open farms",

- the repeated use of one anthelmintic family,

- a large contribution of worms that survive drenching by treating hosts when few infective larvae are available or by the management of pastures (long winter withdrawal of hosts from pastures). 
These factors interact with each other and they represent "risk indices" that select for anthelmintic resistance. If a farm presents one of these characteristics, for example, an important introduction of hosts, this does not mean that resistance will appear soon on the farm, if no anthelmintic treatment is given. On the contrary, if the farm is "open" and if one class of anthelmintic is exclusively used at turn out, then we can suspect that resistance will appear soon. As all indices, these points constitute clues which may help the investigator explain why resistance develops on this farm, and not on the other one. It seems important to consider these breeding management factors in future epidemiological surveys in order to be able to describe historical events that may be responsible for the spread of anthelmintic resistance. Concerning the farmers advice, it becomes more and more necessary to give them clear recommendations, instead of diffusing statements that have not been demonstrated. Moreover, for each farm, the status of anthelmintic resistance of the worm population must be determined before pasture management is proposed. In conclusion, the most efficient way to limit the increase of anthelmintic resistance remains the reduction of the selection pressure by drugs, and optimal timing to maximise their efficacy. The treatment of the most probably infected hosts instead of the anthelmintic treatment of the whole herd $[54,94]$ would keep a part of the parasite community from being submitted to selection pressure.

\section{ACKNOWLEDGEMENTS}

Most of the investigations from which data are presented here were funded by regional (Région Centre, Région Poitou-Charentes, GIS Massif Central) or binational (PRAD France-Morocco and PARS Morocco) programs. A. Silvestre and V. Leignel were grateful recipients of grants from INRA and the French Ministry of Research, respectively. The techni- cal help of the Redon and Orcival INRA staff is gratefully acknowledged for collecting data in the Auvergne survey.

\section{REFERENCES}

[1] Ait-Baba A., Réflexion sur l'élevage pastoral au Maroc, Terre et Vie 12 (1994) 1-5.

[2] Barger I.A., Southcott W.H., Parasitism and production in weaner sheep grazing alternately with cattle, Aust. J. Exp. Agr. Anim. Husb. 18 (1978) 340-346.

[3] Barger I.A., Siale K., Banks D.J.D., Le Jambre L.F., Rotational grazing for control of gastrointestinal nematodes of goats in a wet tropical environment, Vet. Parasitol. 53 (1994) 109-116.

[4] Barnes E.H., Dobson R.J., Barger I.A., Worm control and anthelmintic resistance: adventures with a model, Parasitol. Today 11 (1995) 56-63.

[5] Barton N.J., Development of anthelmintic resistance in nematodes from sheep in Australia subjected to different treatment frequencies, Int. J. Parasitol. 13 (1983) 125-132.

[6] Beech R.N., Prichard R.K., Scott M.E., Genetic variability of the beta- tubulin genes in benzimidazole-susceptible and -resistant strains of Haemonchus contortus, Genetics 138 (1994) 103-110.

[7] Berrag B., Cabaret J., Efficacité insuffisante d'un anthelminthique à base de tetramisole: une histoire de dose, Espace Vet. 22 (2000) 10-11.

[8] Besier R.B., Hopkins D.L., Anthelmintic dose selection by farmers, Aust. Vet. J. 65 (1988) 193-194.

[9] Bjorn H., Workshop summary: anthelmintic resistance, Vet. Parasitol. 54 (1994) 321-325.

[10] Cabaret J., Anthelmintic resistance in goats: from fiction to facts, in: Proceeding of the 7 th international conference on goats (2000) Tours-Poitiers, France, 15-21 mai 2000, pp. 793794.

[11] Cabaret J., Gasnier N., Farm history and breeding management influences on the intensity and specific diversity of nematode infection of dairy goats, Vet. Parasitol. 53 (1994) 219-232.

[12] Cabaret J., Mangeon N., Fertilizers on pastures in relation to infestation of goats with strongyles, small lungworms and Moniezia, Small Rumin. Res. 13 (1994) 269-276.

[13] Cabaret J., Ouhelli H., Fertility of parasitic strongyles in the digestive system of sheep under natural conditions, Rev. Med. Vet. 135 (1984) 627-633.

[14] Cabaret J., Ouhelli H., Dakkak A., Comparative efficacy of fenbendazole and tetramisole against helminths of sheep in Morocco. II. Gastrointestinal helminths, Recl. Méd. Vét. 155 (1979) 785-793. 
[15] Cabaret J., Anjorand N., Leclerc C., Helminthoses of dairy goats in Touraine. Interpretation of faecal examinations, Bull. Mens. Soc. Vet. Prat. Fr. 68 (1984) 285-296.

[16] Cabaret J., Anjorand N., Leclerc C., Dairy goat farms in Touraine. I. Management, parasitism and estimation of disease in adult goats, Recl. Méd. Vét. 162 (1986) 575-585.

[17] Cabaret J., Anjorand N., Leclerc C., Baril G., Goat farming in Touraine, France. II. Use of anthelmintics in adult goats, Recl. Méd. Vét. 162 (1986) 979-987.

[18] Cabaret J., Anjorand N., Leclerc C., Parasitic risk factors on pastures of French dairy goat farms, Small Rumin. Res. 2 (1989) 69-78.

[19] Cabaret J., Bouilhol M., Mage C., Managing helminths of ruminants in organic farming, Vet. Res. 33 (2002) 625-640.

[20] Carmichael I., Visser R., Schneider D., Soll M., Haemonchus contortus resistance to ivermectin, J. S. Afr. Vet. Assoc. 58 (1987) 93.

[21] Caron P., Hubert B., De l'analyse des pratiques à la construction d'un modèle d'évolution des systèmes d'élevage: application à la région Nordeste du Brésil, Rev. Elev. Méd. Vét. Pays Trop. 53 (2000) 37-53.

[22] Chartier C., Hoste H., La thérapeutique anthelminthique chez les caprins, Point Vét. 28 (1997) 1907-1914.

[23] Chartier C., Pors I., Hubert J., Rocheteau D., Benoit C., Bernard N., Prevalence of anthelmintic resistant nematodes in sheep and goats in western France, Small Rumin. Res. 29 (1998) 33-41.

[24] Chartier C., Lespine A., Hoste H., Alvinerie M., Endectocides in goats: pharmacology, efficacy and conditions of use in the context of anthelmintic resistance, in: VIIIe Rencontres Recherches Ruminants (2001) Paris, France, 5-6 December 2001, pp. 181-186.

[25] Chartier C., Soubirac F., Pors I., Silvestre A., Hubert J., Couquet C., Cabaret J., Prevalence of anthelmintic resistance in gastrointestinal nematodes of dairy goats under extensive management conditions in southwestern France, J. Helminthol. 75 (2001) 325-330.

[26] Coles G.C., Cattle nematodes resistant to anthelmintics: why so few cases?, Vet. Res. 33 (2002) 481-489.

[27] Coles G.C., Bauer C., Borgsteede F.H.M., Geerts S., Klei T.R., Taylor M.A., Waller P.J., World Association for the Advancement of Veterinary Parasitology (W.A.A.V.P.) methods for the detection of anthelmintic resistance in nematodes of veterinary importance, Vet. Parasitol. 44 (1992) 35-44

[28] Coles G.C., Papadopoulos E., Himonas C.A., Tubulin, resistance and worms, Parasitol. Today 11 (1995) 183-184.
[29] Coles G.C., Watson C.L., Anziani O.S., Ivermectinresistant Cooperia in cattle, Vet. Rec. 148 (2001) 283-284.

[30] Conder G.A., Campbell W.C., Chemotherapy of nematode infections of veterinary importance, with special reference to drug resistance, Adv. Parasitol. 35 (1995) 1-84.

[31] Dorchies P., Resistance to anthelmintics: an outline of the problems, Rev. Med. Vet. 142 (1991) 8-9.

[32] Dorchies P., Nicolas J., Gevrey J., Mage C., Anthelmintic treatment of sheep; preventing the risks of the appearance of drug resistance, Rev. Med. Vet. (Toulouse) 141 (1990) 379-381.

[33] Dorny P., Claerebout E., Vercruysse J., Sani R., Jalila A., Anthelmintic resistance in goats in peninsular Malaysia, Vet. Parasitol. 55 (1994) 327-342.

[34] Drudge J.H., Szanto J., Wyant Z.N., Elam G., Field studies on parasitic control in sheep: comparison of thiabendazole, ruelene, and phenothiazine, Am. J. Vet. Res. 25 (1964) 1512-1518.

[35] Dupuy J., Chartier C., Sutra J.F., Alvinerie M., Eprinomectin in dairy goats: dose influence on plasma levels and excretion in milk, Parasitol. Res. 87 (2001) 294-298.

[36] Edwards J.R., Wroth R., Chaneet G.C.D., Besier R.B., Karlsson J., Morcombe P.W., Dalton-Morgan G., Roberts D., Survey of anthelmintic resistance in Western Australian sheep flocks. 1. Prevalence. 2. Relationship with sheep management and parasite control practices, Aust. Vet. J. 63 (1986) 135-144

[37] Egerton J.R., Suhayda D., Eary C.H., Laboratory selection of Haemonchus contortus for resistance to ivermectin, J. Parasitol. 74 (1988) 614-617.

[38] Elard L., Humbert J.F., Importance of the mutation of amino acid 200 of the isotype 1 betatubulin gene in the benzimidazole resistance of the small-ruminant parasite Teladorsagia circumcincta, Parasitol. Res. 85 (1999) 452-456.

[39] Elard L., Comes A.M., Humbert J.F., Sequences of beta-tubulin cDNA from benzimidazole-susceptible and -resistant strains of Teladorsagia circumcincta, a nematode parasite of small ruminants, Mol. Biochem. Parasitol. 79 (1996) 249-253.

[40] Faye B., Interrelationships between health status and farm management system in French dairy herds, Prev. Vet. Med. 12 (1991) 133-152.

[41] Gasnier N., Isolation of the nematode Teladorsagia circumcincta in dairy-goat farms. Influence on morphological, ecological and genetic variability, Ph.D. thesis, Université Francois Rabelais, Tours, France, 1994, p. 138.

[42] Geerts S., Bertels G., Balis B., Brandt J., Kumar V., Benzimidazole resistance in nematodes on a dairy goat farm in Belgium, Vlaams Diergeneeskd. Tijdschr. 59 (1990) 90-92. 
[43] Gould F., Testing Bt refuge strategies in the field, Nat. Biotechnol. 18 (2000) 266-267.

[44] Green P.E., Forsyth B.A., Rowan K.J., Payne G., The isolation of a field strain of Haemonchus contortus in Queensland showing multiple anthelmintic resistance, Aust. Vet. J. 57 (1981) 79-84.

[45] Griffith D.M., Agroforestry: a refuge for tropical biodiversity after fire, Conserv. Biol. 14 (2000) 325-326.

[46] Gruner L., Calamel M., Parasitisme des ovins en transhumance dans les Alpes-Maritimes, Bulletin Technique de l'Elevage Ovin 6 (1984) 13-16.

[47] Hazelby C.A., Probert A.J., Rowlands D.A.T., Anthelmintic resistance in nematodes causing parasitic gastroenteritis of sheep in the UK, J. Vet. Pharmacol. Ther. 17 (1994) 245-252.

[48] Hennessy D.R., Sangster N.C., Steel J.W., Collins G.H., Comparative pharmacokinetic behaviour of albendazole in sheep and goats, Int. J. Parasitol. 23 (1993) 321-325

[49] Hennessy D.R., Sangster N.C., Steel J.W., Collins G.H., Comparative pharmacokinetic disposition of closantel in sheep and goats, $\mathrm{J}$. Vet. Pharmacol. Ther. 16 (1993) 254-260.

[50] Hertzberg H., Rossmann J., Kohler L., Willi U., Benzimidazole-resistance in gastrointestinal nematodes of sheep and goats in Switzerland, Wiener Tierarztl. Monats. 87 (2000) 3-9.

[51] Himonas C., Papadopoulos E., Anthelmintic resistance in imported sheep, Vet. Rec. 134 (1994) 456.

[52] Hoekstra R., Borgsteede F.H.M., Boersema J.H., Roos M.H., Selection for high levamisole resistance in Haemonchus contortus monitored with an egg-hatch assay, Int. J. Parasitol. 27 (1997) $1395-1400$

[53] Hong C., Hunt K.R., Coles G.C., Occurrence of anthelmintic resistant nematodes on sheep farms in England and goat farms in England and Wales, Vet. Rec. 139 (1996) 83-86.

[54] Hoste H., Chartier C., Le Frileux Y., Control of gastrointestinal parasitism with nematodes in dairy goats by treating the host category at risk, Vet. Res. 33 (2002) 531-545.

[55] Jackson F., Anthelmintic resistance - the state of play, Br. Vet. J. 149 (1993) 123-138

[56] Jackson F., Jackson E., Little S., Coop R.L., Russel A.J.F., Prevalence of anthelmintic-resistant nematodes in fibre-producing goats in Scotland, Vet. Rec. 131 (1992) 282-285.

[57] Juraj H., Cady A.B., Uetz G.W., Modular habitat refugia enhance generalist predators and lower plant damage in soybeans, Environ. Entomol. 29 (2000) 383-393.

[58] Kerboeuf D., Winter survival of trichostrongyle larvae: a study using tracer lambs, Res. Vet. Sci. 38 (1985) 364-367.
[59] Kettle P.R., Vlassoff A., Reid T.C., Horton C.T., A survey of nematode control measures used by milking goat farmers and of anthelmintic resistance on their farms, N. Z. Vet. J. 31 (1983) 139-143.

[60] Kieran P.J., Moxidectin against ivermectin-resistant nematodes - a global view, Aust. Vet. J. 71 (1994) 18-20.

[61] Kwa M.S.G., Veenstra J.G., Roos M.H., Molecular characterisation of beta -tubulin genes present in benzimidazole-resistant populations of Haemonchus contortus, Mol. Biochem. Parasitol. 60 (1993) 133-143.

[62] Kwa M.S.G., Veenstra J.G., Roos M.H., Benzimidazole resistance in Haemonchus contortus is correlated with a conserved mutation at amino acid 200 in beta-tubulin isotype 1, Mol. Biochem. Parasitol. 63 (1994) 299-303.

[63] Laurent C., Remy J., L'exploitation agricole en perspective, Courrier de l'Environnement de l'INRA 41 (2000) 5-22.

[64] Le Fur C., Approche éco-épidémiologique de la tremblante du mouton: étude du rôle de l'environnement dans le pays Basque français, $\mathrm{Ph} . \mathrm{D}$. thesis, École Nationale Vétérinaire de Nantes, France, 2001, p. 121.

[65] Le Jambre L.F., Southcott W.H., Dash K.M., Resistance of selected lines of Haemonchus contortus to thiabendazole, morantel tartrate and levamisole, Int. J. Parasitol. 6 (1976) 217-222.

[66] Leignel V., Diversité génétique et résistance aux benzimidazoles chez Teladorsagia circumcincto (Nematoda, Trichostrongylidae), parasite de petits ruminants, Ph.D. thesis, Université Montpellier II, Montpellier, France, 2000, p. 170.

[67] Maingi N., Bjorn H., Thamsborg S.M., Dangolla A., Kyvsgaard N.C., Worm control practices on sheep farms in Denmark and implications for the development of anthelmintic resistance, Vet. Parasitol. 66 (1997) 39-52.

[68] Maingi N., Bjorn H., Thamsborg S.M., Munyua W.K., Gathumat J.M., Dangolla A., Worm control practices on sheep farms in Nyandarua District of Kenya, Acta Trop. 68 (1998) 1-9.

[69] Martin P.J., Selection for thiabendazole resistance in Ostertagia spp. by low efficiency anthelmintic treatment, Int. J. Parasitol. 19 (1989) 317-325.

[70] Martin P.J., Jambre L.F.1., Claxton J.H., The impact of refugia on the development of thiabendazole resistance in Haemonchus contortus, Int. J. Parasitol. 11 (1981) 35-41.

[71] Martin P.J., Anderson N., Jarrett R.G., Brown T.H., Ford G.E., Effects of a preventive and suppressive control scheme on the development of thiabendazole-resistance in Ostertagia spp., Aust. Vet. J. 58 (1982) 185-190.

[72] Martin P.J., Anderson N., Lwin T., Nelson G., Morgan T.E., The association between frequency 
of thiabendazole treatment and the development of resistance in field isolates of Ostertagia spp. of sheep, Int. J. Parasitol. 14 (1984) 177-181.

[73] McKenna P.B., Anthelmintic resistance in cattle nematodes in New Zealand: is it increasing, N. Z. Vet. J. 44 (1996).

[74] Michel J.F., Strategies for the use of anthelmintics in livestock and their implications for the development of drug resistance, Parasitology 90 (1985) 621-628.

[75] Michel J.F., Cawthorne R.J.G., Anderson R.M., Armour J., Clarkson M.J., Thomas R.J., Resistance to anthelmintics in Britain: husbandry practices and selective pressure, Facts and reflections. IV. Resistance of parasites to anthelmintics. A workshop in the Commission of European Communities animal pathology programme held at the Central Veterinary Institute, Lelystad, The Netherlands, 1982, pp. 41-50.

[76] Prichard R.K., Biochemistry of anthelmintic resistance, Resistance of parasites to antiparasitic drugs: Round Table Conference, VII International Congress of Parasitology, Paris, Texas, United States, 1990.

[77] Prichard R.K., Anthelmintic resistance, Vet. Parasitol. 54 (1994) 259-268.

[78] Requejo-Fernandez J.A., Martinez A., Meana A., Rojo-Vazquez F.A., Osoro K., Ortega-Mora L.M., Anthelmintic resistance in nematode parasites from goats in Spain, Vet. Parasitol. 73 (1997) 83-88.

[79] Richard S., Cabaret J., Individual variations in efficacy of fenbendazole against the small lungworm Muellerius capillaris in dairy goats, Small Rumin. Res. 8 (1992) 1-2.

[80] Roos M.H., Boersema J.H., Borgsteede F.H.M., Cornelissen J., Taylor M., Ruitenberg E.J., Molecular analysis of selection for benzimidazole resistance in the sheep parasite Haemonchus contortus, Mol. Biochem. Parasitol. 43 (1990) $77-88$

[81] Sangster N.C., Anthelmintic resistance: past, present and future, Int. J. Parasitol. 29 (1999) 115-124.

[82] Saul A., Computer model of the maintenance and selection of genetic heterogeneity in polygamous helminths, Parasitology 111 (1995) 531-536.

[83] Scherrer A.M., Pomroy W.E., Charleston W.A.G., Anthelmintic usage on goat farms in New Zealand. Results of a postal survey, N. Z. Vet. J. 38 (1990) 133-135.

[84] Schneider C.J., Smith T.B., Larison B., Moritz C., A test of alternative models of diversification in tropical rainforests: ecological gradients vs. rainforest refugia, Proc. Natl. Acad. Sci. USA 96 (1999) 13869-13873.

[85] Scott E.W., Duncan J.L., McKellar Q.A., Coop R.L., Jackson F., Mitchell G.B.B., Benzimidazole resistance in sheep nematodes, Vet. Rec. 128 (1991) 618-619.

[86] Silvestre A., Benzimidazole resistance in nematode communities of small ruminant digestive tract: genetic mechanisms and environmental factors, in Genetic, Ph.D. thesis, Université François Rabelais, Tours, France, 2000, p. 158.

[87] Silvestre A., Chartier C., Sauve C., Cabaret J., Relationship between helminth species diversity, intensity of infection and breeding management in dairy goats, Vet. Parasitol. 94 (2000) 91-105.

[88] Silvestre A., Cabaret J., Humbert J.F., Effect of benzimidazole under-dosing on the resistant allele frequency in Teladorsagia circumcincta (Nematoda), Parasitology 123 (2001) 103-111.

[89] Smith G., Grenfell B.T., Isham V., Cornell S., Anthelmintic resistance revisited: under-dosing, chemoprophylactic strategies, and mating probabilities, Int. J. Parasitol. 29 (1999) 77-91.

[90] Stafford K., Coles G.C., Nematode control practices and anthelmintic resistance in dairy calves in the south west of England, Vet. Rec. 144 (1999) 659-661.

[91] Sykes A.R., McFarlane R.G., Familton A.S., Parasites, immunity and anthelmintic resistance, in: Progress in sheep and goat research, $\mathrm{CAB}$ International, Wallingford, UK, 1992, pp. 179 191.

[92] Tang J.D., Collins H.L., Metz T.D., Earle E.D., Zhao J.Z., Roush R.T., Shelton A.M., Greenhouse tests on resistance management of $\mathrm{Bt}$ transgenic plants using refuge strategies, J. Econ. Entomol. 94 (2001) 240-247.

[93] Van Wyk J.A., Refugia - overlooked as perhaps the most potent factor concerning the development of anthelmintic resistance, Onderstepoort J. Vet. Res. 68 (2001) 55-67.

[94] Van Wyk J.A., Bath G.F., The FAMACHA ${ }^{\odot}$ system for managing haemonchosis in sheep and goats by clinically identifying individual animals for treatment, Vet. Res. 33 (2002) 509-529.

[95] Van Wyk J.A., Stenson M.O., Van der Merwe J.S., Vorster R.J., Viljoen P.G., Anthelmintic resistance in South Africa: surveys indicate an extremely serious situation in sheep and goat farming, Onderstepoort J. Vet. Res. 66 (1999) 273-284

[96] Varady M., Praslicka J., Corba J., Vesely L., Multiple anthelmintic resistance of nematodes in imported goats, Vet. Rec. 132 (1993) 387-388

[97] Vermunt J.J., West D.M., Pomroy W.E., Multiple resistance to ivermectin and oxfendazole in Cooperia species of cattle in New Zealand, Vet. Rec. 137 (1995) 43-45.

[98] Walley J.K., Tetramisole (dl 2,3,5,6tetrahydro-6-phenyl-imidazo (2,1-b) thiazole hydrochloride--Nilverm) in the treatment of gastro-intestinal worms and lungworms in do- 
mestic animals. 1. Sheep and goats, Vet. Rec. 78 (1966) 406-414.

[99] Walter R., Epperson B.K., Geographic pattern of genetic variation in Pinus resinosa: area of greatest diversity is not the origin of postglacial populations, Mol. Ecol. 10 (2001) 103-111.

[100] Warriss P.D., Edwards J.E., Estimating the liveweight of sheep from chest girth measurements, Vet. Rec. 137 (1995) 123-124.
[101] Wood I.B., Amaral N.K., Bairden K., Duncan J.L., Kassai T., Malone J.B., Jr., Pankavich J.A., Reinecke R.K., Slocombe O., Taylor S.M., Vercruysse J., World Association for the Advancement of Veterinary Parasitology (W.A.A.V.P.) second edition of guidelines for evaluating the efficacy of anthelmintics in ruminants (bovine, ovine, caprine), Vet. Parasitol. 58 (1995) 181-213.

To access this journal online: www.edpsciences.org 